\section{СПИСОК ЛИТЕРАТУРЫ}

1. Проблемы устойчивого развития подсистем глобальной морской транспортной индустрии: Монография/Под ред. Н. Примачева, Н. Примачев, Klimek. - Gdansk, Одесса, 2014. - 316 c.

2. Chin C. B. N. Cruising in the Global Economy /C. B. N. Chin Hampshire: ASHGATE, 2008. - $184 \mathrm{p}$

3. Голубкова И. А. Экономический механизм развития круизного судоходства Украины: Моногр./И. А. Голубкова.- Одесса: ИПРиЭЭИ НАН Украины, 2011. - 320 с.

4. Schulz A. Kreuzfahrten und Schiffsverkehr im Tourismus / A. Schulz, J. Auer. - Munchen: Oldenbourg, 2010. - 398 p.
5. Мельник І. Л. Іманентні особливості системи управління іноваціями круїзних судноплавних компаній [Електронний ресурс]/ І. Л. Мельник //Ефективна економика. - 2014. №12. - Режим доступу: http://www.economy. nayka.com.ua

6. Мальська М. П. Міжнародний туризм i сфера послуг: підручник /.М.П.Мальська, Н.В. Антонюк, Н.М. Ганина. -К.: Знання, 2008. - 661 с.

7. Steinecke A. Themenwelten im Tourismus/ A. Steinecke.- Munchen: Oldenbourg, 2009. $-348 \mathrm{c}$.

8. Холловей Дж. К. Туристический бизнес: пер.с англ. / Н. Тейлор. - К.: Знання, 2007.- $798 \mathrm{c}$.

Рецензент д.э.н., профессор ОНМА Примачев Н.Т. Эксперт редакционной коллегии к.э.н., дочент УкрГУЖТ Зубенко В.А.

УДК: 336.713

\title{
ФОРМУВАННЯ ЕФЕКТИВНОЇ ПРОЦЕНТНОЇ ПОЛІТИКИ ВІТЧИЗНЯНИХ БАНКІВ: ПРАКТИЧНИЙ ДОСВІД ЇЇ РЕАЛІЗАЦІЇ
}

Остропольська $С$. В., к.е.н.

(ПВНЗ «Міжнародний науково-технічний університет ім. ак. Юрія Бугая»)

В статті висвітлюються питання формування $і$ реалізації ефективної процентної політики банків України. 3 метою аналізу ефективності процентної політики проведено аналіз банківської діяльності (на прикладі ПАТ «Укргазбанк»), щңо є одним із найважлливіших завдань економічного аналізу, вирімення якого трунтується на застосуванні методу коефіцієнтів. Підвищення ефективності діяльності банку є надзвичайно важливим. 3 иієє метою автором запропоновано низку заходів щзоо підвищення ефективності процентної політики банку.

Ключові слова: банк, процент, процентна політика, процентна ставка, депозит, кредит.

\section{ФОРМИРОВАНИЕ ЭФФЕКТИВНОЙ ПРОЦЕНТНОЙ ПОЛИТИКИ ОТЕЧЕСТВЕННЫХ БАНКОВ: ПРАКТИЧЕСКИЙ ОПЫТ ЕЕ РЕАЛИЗАЦИИ}

\author{
Остропольская Е. В., к.э.н. \\ (ЧВУЗ «Международный научно-технический университет им. ак. Юрия Бугая») \\ В статье освещены вопросы формирования и реализации эффективной процентной \\ политики банков Украины. С иелью исследования эффективности проиентной политики
}


проведен анализ банковской деятельности (на примере банка «Укргазбанк»), что является одной из важнейших задач экономического анализа, решение которой основывается на применении метода коэффищиентов. Повышение эффективности деятельности банка является чрезвычайно важным. С этой целью автором предложен ряд мероприятий относительно повышения эффективности процентной политики банка.

Ключевые слова: банк, процент, процентная политика, процентная ставка, депозит, кредит.

\section{THE FORMATION OF EFFECTIVE INTEREST RATE POLICY OF NATIONAL BANKS: THE PRACTICAL EXPERIENCE OF ITS IMPLEMENTATION}

\section{Ostropolska Y.V., candidate of economic sciences (the academician Yuriy Bugay Internationa Scientific and Technical University)}

The article highlights the issues of formation and implementation of efficient interest rate policy of Ukrainian banks. Strategic direction of enhancing the effectiveness of interest rate policy of banks is the creation of conceptual basis for the formation and implementation of interest rate policy of the bank and methodological support of its application, that provides a set of methods, instruments and tools aimed at improving the efficiency of deposit and credit operations while maintaining an acceptable level of interest rate risk and expand the client base of the bank in the conditions of economic uncertainty. To study the effectiveness of interest rate policy the analysis of banking activity (on the example of the bank "Ukrgasbank") was made which was based on the application of method of coefficients. Improving the efficiency of the bank's activities is extremely important. The author proposes a number of measures for strengthening the effectiveness of interest rate policy of the bank.

The practical application of the proposed directions of improvement of the interest rate policy of the bank will strengthen its financial condition and improve its financial performance in unstable economic environment.

Keywords: bank, finance, interest rate policy, interest rate, deposit, loan.

Постановка проблеми. На сучасному етапі розвитку економіки України кредитні та депозитні відносини між банками та економічними суб'єктами мають велике значення. Вони здійснюються на платній основі шляхом встановлення депозитного i позичкового відсотка, рівень якого визначається відповідно до процентної політики банку. Процентна політика є однією 3 ключових складових елементів управління банківською діяльністю. Вивчення динаміки руху процентних ставок показує, що процентна політика характеризує непрості механізми оцінки ощадної та кредитної політики банку. В інтересах банку проводити таку процентну політику, яка б повною мірою забезпечувала йому отримання необхідного рівня прибутку i була приваблива для існуючих і потенційних клієнтів. Проте за умов економічної і політичної нестабільності в країні банки стикаються зі значними труднощами у формуванні i реалізації ефективної процентної політики.

Аналіз останніх досліджень $i$ публікацій. Окремі аспекти цієї проблеми висвітлені у наукових працях таких вчених, як: Дж. Сінкі [8], П. Роуза [9], Л. Примостки [5], О. Васюренка [1], В. Вітлінського [2], В. К. Раєвського [4], І. Сало та інших [4].

\section{Виділення невирішених частин}

загальної проблеми. Разом з тим, незважаючи на проведені дослідження, залишаються дискусійними тлумачення базових понять процентної політики банку; не до кінця вивчені фактори іï формування, а наявні рекомендації щодо підвищення іiі ефективності не дають бажаних результатів. Цим визначився вибір теми статті, мета, завдання і зміст виконаного дослідження.

Мета дослідження: на основі системного підходу надати оцінку процесу формування і реалізації процентної політики банку на прикладі ПАТ «Укргазбанк» i виробити практичні рекомендації щодо 
підвищення ефективності процентної політики цього банку.

$\begin{array}{ccc}\text { Виклад } & \text { основного } & \text { матеріалу } \\ \text { дослідження. } & \text { Оцінка } & \text { ефективності }\end{array}$
банківської діяльності $є$ одним із найважливіших завдань економічного аналізу, вирішення якого грунтується на застосуванні методу коефіцієнтів. Сутність методу коефіцієнтів полягає у побудові системи взаємозв'язаних показників, які всебічно характеризують стан i динаміку об'єкта дослідження. Розраховані коефіцієнти дають змогу фінансовому аналітику поглибити висновки про фінансовий стан банку, оскільки абсолютні значення дають повну картину лише у виняткових випадках.

Показники ефективності розраховують за результатами діяльності банку за рік. При розрахунках за квартал чи півріччя показники необхідно приводити до річного рівня.

Основними показниками, які характеризують прибутковість банку, є такі:

- норма прибутку на капітал (рентабельність капіталу); активів;

- рентабельність (прибутковість)

- рентабельність витрат;
- чистий спред;

- чиста процентна маржа;

- рівень іншого операційного доходу.

Ці показники та розглянуті вище коефіцієнти загальної дохідності активів та дохідності процентних активів дають змогу досить повно охарактеризувати діяльність банку з погляду їі ефективності.

Норма прибутку на капітал (RK) характеризує ефективність використання капіталу i розраховується як відношення чистого прибутку (П) до балансового капіталу (К). Даний коефіцієнт показує, скільки чистого прибутку припадає на 1 грн капіталу банку i характеризує економічну віддачу капіталу. У світовій практиці норма прибутку на капітал (ROE) $є$ основним показником ефективності діяльності банку. Норма прибутку на капітал розраховується за формулою:

$$
\mathrm{RK}=(\Pi / \mathrm{K}) 100 \% \text {, }
$$

де П - прибуток;

К - балансовий капітал.

Банк працює ефективно у тому разі, коли значення показника не менше $15 \%$.

Таблиия. 1

Динаміка норми прибутку на капітал ПАТ «Укргазбанк» за 2012 - 2014 рр.

\begin{tabular}{|l|l|l|l|}
\hline Показник & $01.01 .2013 \mathrm{p}$. & $01.01 .2014 \mathrm{p}$. & $01.01 .2015 \mathrm{p}$. \\
\hline Чистий прибуток / збиток, тис. грн. & 1100254 & 1001973 & -2801124 \\
\hline Балансовий капітал, тис. грн. & 3814550 & 4522482 & 1570507 \\
\hline Норма прибутку на капітал,\% & 28,84 & 22,16 & $-178,36$ \\
\hline
\end{tabular}

Дані табл. 1 свідчать про зменшення ефективності використання капіталу на протязі аналізованих років. Так, на 01.01.2014p. сума прибутку зменшилась на $8,93 \%$ у порівнянні 3 показником на 01.01.2013p. Негативна тенденція зменшення рівня прибутковості банку спостерігалась і на протязі всього 2014 року. Так, на 01.01.2015p. спостерігались збитки у сумі -2801124 тис.грн., що свідчить про низьку ефективність роботи банку.

Рентабельність

активів ${ }^{\circ}(\mathrm{Pa})$ визначається відношенням чистого прибутку до сукупних активів банку, тобто до ресурсів, що управляються.

$$
\mathrm{Ra}=(\Pi / \mathrm{A}) * 100 \%,
$$

де П - прибуток;

А - активи банку.

Банк ефективно використовує наявні ресурси в тому випадку, коли значення показника не менше $1 \%$.

Дані табл. 2 дозволяють констатувати також стійку негативну тенденцію щодо зниження показників рентабельності активів ПАТ «Укргазбанк» в аналізованих періодах. Даний показник відображає внутрішню політику банку, професіоналізм його менеджерів, які повинні підтримувати оптимальну структуру активів і пасивів 3 погляду доходів і витрат. Тому у світовій практиці багато спеціалістів вважають даний показник (ROA) найкращим показником для

Вісник економіки транспорту і промисловості № 51, 2015 
оцінювання ефективності роботи менеджерів банку.

Табличя 2

Рентабельність активів ПАТ «Укргазбанк» за 2012 - 2014 рр.

\begin{tabular}{|l|c|c|c|}
\hline \multicolumn{1}{|c|}{ Показник } & $01.01 .2013 \mathrm{p}$. & $01.01 .2014 \mathrm{p}$. & $01.01 .2015 \mathrm{p}$. \\
\hline Чистий прибуток / збиток, тис. грн. & 1100254 & 1001973 & -2801124 \\
\hline Сукупні активи, тис. грн. & 20997238 & 23793944 & 21027912 \\
\hline Рентабельність активів, \% & 5,24 & 4,21 & 1,33 \\
\hline
\end{tabular}

Рентабельність витрат визначається як відношення прибутку до витрат.

$$
\mathrm{RB}=(\Pi / \mathrm{B}) * 100 \%,
$$

де П - прибуток;

В - витрати.

Дані табл. 3 розкривають структуру витрат ПАТ «Укргазбанк» за аналізований період i дозволяють стверджувати, що у структурі витрат найбільшу питому вагу мають процентні витрати та адміністративні витрати. Значне зниження рентабельності активів ілюструє низький рівень віддачі витрат банку й показує зниження суми

прибутку, що припадає на одиницю витрат.

Чистий спред (ЧС) характеризує рівень узгодженості процентної політики банку за кредитними і депозитними операціями.

$$
\text { ЧC }=\frac{\Pi Д}{К \Pi} * 100-\frac{\Pi B}{\Pi 3} * 100,
$$

де ПД - процентні доходи за кредитними операціями;

КП - кредитний портфель;

ПВ - процентні витрати за

депозитами;

ПЗ - підпроцентні зобов'язання.

Табличя 3

Рентабельність витрат ПАТ «Укргазбанк» за 2012 - 2014 рр.

\begin{tabular}{|l|c|c|c|}
\hline \multicolumn{1}{|c|}{ Показник } & $01.01 .2013 \mathrm{p}$. & $01.01 .2014 \mathrm{p}$. & $01.01 .2015 \mathrm{p}$. \\
\hline 1. Прибуток / збиток, тис. грн. & 1100254 & 1001973 & -2801124 \\
\hline 2. Витрати, тис. грн., у тому числі & 2114332 & 2181232 & 2838940 \\
\hline у тому числі: & & & \\
\hline 2.1 Процентні витрати, тис. грн. & 1361384 & 1384006 & 1727795 \\
\hline 2.2 Комісійні витрати, тис. грн. & 30728 & 30311 & 48205 \\
\hline $\begin{array}{l}2.3 \text { Адміністративні та інші операційні } \\
\text { витрати, тис. грн. }\end{array}$ & 722220 & 766915 & 1062940 \\
\hline 3. Рентабельність витрат, \% & 52,04 & 45,94 & 98,67 \\
\hline
\end{tabular}

Таблиия 4

Чистий спред по ПАТ «Укргазбанк» за 2012 - 2014 рр.

\begin{tabular}{|l|c|c|c|}
\hline \multicolumn{1}{|c|}{ Показник } & $01.01 .2013 \mathrm{p}$. & $01.01 .2014 \mathrm{p}$. & $01.01 .2015 \mathrm{p}$. \\
\hline Процентні доходи, тис. грн. & 2165829 & 2357308 & 2805330 \\
\hline Кредитний портфель, тис. грн. & 8675121 & 10257721 & 10034858 \\
\hline Процентні витрати, тис. грн. & 1361384 & 1384006 & 1727795 \\
\hline Підпроцентні зобов’язання, тис. грн. & 15493052 & 17264172 & 18936548 \\
\hline Чистий спред, \% & 16,18 & 14,96 & 18,84 \\
\hline
\end{tabular}

Проведений аналіз чистого спреду пов'язаний із процентною політикою банку, яка відображається у динаміці процентних ставок за активними і пасивними операціями. Чистий спред - це різниця між середніми процентними ставками, отриманими i сплаченими. За його допомогою визначається необхідна мінімальна різниця між ставками за активними і пасивними операціями, яка дасть змогу банку покрити витрати, але не принесе

Вісник економіки транспорту і промисловості № 51, 2015 
прибутку (мінімальне значення показника 0). Дані таблиці 4 дозволяють констатувати, що у цілому ПАТ «Укргазбанк» проводить зважену процентну політику. За період з 01.01.2013p. по 01.01.2015p чистий спред збільшився на $2,66 \%$. I, в цілому, за аналізований період, значення показника чистого спреду було значно вищим за його оптимальне значення (оптимальне значення показника не менше $1,25 \%)$.

Чиста процентна маржа (ЧПМ) дає змогу оцінити здатність банку утворювати

чистий процентний дохід, використовуючи загальні активи. До деякої міри можна вважати, що цей показник характеризує ефективність структури активів банку. Чиста процентна маржа обчислюється як відношення чистого процентного доходу (ЧПД) до загальних активів банку (А):

$$
\begin{aligned}
& \text { ЧПМ = (ПД - ПВ) / А * 100\%, } \\
& \text { де ПД - процентний дохід; } \\
& \text { ПВ - процентні витрати. }
\end{aligned}
$$

Таблиия 5

Чиста прочентна маржа по ПАТ «Укргазбанк» за 2012 - 2014 рр.

\begin{tabular}{|l|c|c|c|}
\hline \multicolumn{1}{|c|}{ Показник } & $01.01 .2013 \mathrm{p}$. & $01.01 .2014 \mathrm{p}$. & $01.01 .2015 \mathrm{p}$. \\
\hline Процентні доходи, тис. грн. & 2165829 & 2357308 & 2805330 \\
\hline Процентні витрати, тис. грн. & 1361384 & 1384006 & 1727795 \\
\hline \multicolumn{1}{|c|}{ Сукупні активи, тис. грн. } & 20997238 & 23793944 & 21027912 \\
\hline Чиста процентна маржа, \% & 3,83 & 4,09 & 5,12 \\
\hline
\end{tabular}

Аналізуючи чисту процентну маржу, слід брати до уваги іiі призначення: маржа слугує для покриття витрат банку і ризиків, у тому числі й інфляційного, створення прибутку, покриття договірних угод. Оптимальним значенням показника є $4,5 \%$. Зменшення процентної маржі, нижче оптимального значення, на 01.01.2013p. та на 01.01.2014p. сигналізувало про існування у дані періоди загрози банкрутства. Основними причинами зменшення процентної маржі, на нашу думку, було: зниження процентних ставок за кредитами; подорожчання ресурсів; скорочення питомої ваги дохідних активів у загальному їх обсязі; недостатньо ефективна процентна політика. На 01.01.2015p. рівень показника чистої процентної маржі стабілізувався i перевищив оптимальне значення на 0,62 пункти, що свідчить про підвищення ефективності діяльності ПАТ Укргазбанк».

Рівень іншого операційного доходу (Ріод) відносно загальних активів (А) характеризує ступінь залежності фінансового стану банку від «нетрадиційних» доходів.

$$
\text { Ріод }=(\text { ІОД / А }) * 100 \%
$$

Табличя 6

Рівень іншого операчійного доходу по ПАТ «Укргазбанк» за 2012 - 2014 рр.

\begin{tabular}{|l|c|c|c|}
\hline \multicolumn{1}{|c|}{ Показник } & $01.01 .2013 \mathrm{p}$. & $01.01 .2014 \mathrm{p}$. & $01.01 .2015 \mathrm{p}$. \\
\hline Інший операційний дохід, тис. грн. & 13921 & 79594 & 49695 \\
\hline Сукупні активи, тис. грн. & 20997238 & 23793944 & 21027912 \\
\hline Рівень іншого операційного доходу, \% & 0,066 & 0,335 & 0,236 \\
\hline
\end{tabular}

За даними табл. 6 можна констатувати, що у ПАТ «Укргазбанк» існуе незначна диверсифікація додаткових платних послуг i відсутнє хибне тяжіння до спекулятивних прибутків для покриття дефіциту основного процентного доходу банку.

За своїм складом наведені коефіцієнти поєднують періодичні показники, тобто показники, обчислені за відповідний період (дохід, витрати, прибуток), і моментні показники, абсолютний розмір яких визначається на відповідний момент часу згідно з балансом (активи, капітал).

Погіршення показників прибутковості капіталу та активів спричинялося насамперед нарощуванням капітальної бази та сукупних

Вісник економіки транспорту і промисловості № 51, 2015 
активів в банку без адекватного приросту прибутків.

Висновок. Наразі підвищення ефективності діяльності банку є надзвичайно важливим. 3 цією метою пропонуємо наступні напрямки підвищення ефективності процентної політики цього банку:

1) проведення ефективної маркетингової i процентної політики, що дозволить забезпечити зростання групи активів, які приносять процентний дохід;

2) управління ризиком процентних ставок: досягнення цільового рівня чистої процентної маржі, спреду, чистого процентного доходу, прогнозування руху процентних ставок, визначення динамічної структури активів і пасивів на підставі гепаналізу, використання засобів хеджування;

3) узгодженість відсоткових ставок за депозитами і відсоткових ставок за кредитами;

4) формування відсоткової політики банку на ринку банківських ресурсів 3 урахуванням можливостей прибуткового їх розміщення в активи банку;

5) розширення критеріїв диференціації процентних ставок за кредитами і депозитами банку;

6) стимулювання відсотковою політикою більш активного залучення тимчасово вільних коштів населення $\mathrm{y}$ активний банківський оборот;

7) використання інструментарію процентної політики банку для підвищення стабільності і ліквідності банківської установи.

Практичне

застосування запропонованих напрямків удосконалення процентної політики банку буде сприяти зміцненню його фінансового стану та покращенню фінансових результатів діяльності в умовах нестабільного економічного середовища.

\section{СПИСОК ЛІТЕРАТУРИ}

1. Васюренко О. Процентна ставка як чинник особистих заощаджень / О. Васюренко // Фінанси України. - 2013. - № 8. - С. 109115.

2. Вітлінський В. Грошова-кредитна діяльність банків: Навч. Посібник /В. Вітлинський - К.: Вид-во Європ. ун-ту, 2011. $-339 \mathrm{c}$.

3. Мороз А.М." НБУ і грошовокредитна політика" /А.М. Мороз. - Київ: КНЕУ, 2012. - c. 368-375.

4. Раєвський К.С. Методичні рекомендації щодо економічного аналізу діяльності комерційного банку / К. Раєвський, Т. Раєвська // Вісник НБУ. - 2013. - № 4. - с. $35-48$.

5. Примостка Л. Сукупний ризик банку: методика оцінки на основі нормативноіндексної моделі [Текст] / Л. Примостка, О. Лисенок // Вісник Національного банку України : Науково-практичний журнал. - 2013. - N5. - C. $34-38$

6. Річні звіти представлені Департаментом банківського нагляду та Департаментом бухгалтерського обліку та розрахунків в ПАТ “Укргазбанк” за 2012-2014 $\mathrm{pp}$.

7. Фредерік С. Економіка грошей, банківкої справи і фінансових ринків / С. Фредерік / Переклад 3 англ. Наук. Редакція перекладу С. Панчишина. - К.: Основи, 2010. - C. 107-179.

8. Синки Дж. мл. Управление финансами в коммерческих банках /. / Пер.с англ. 4-го переработанного изд. / Под ред. Р.Я. Левиты, Б.С. Пинскера.-М.:Catalaxy, 2010, c. 716-745.

9. П. Роуз Банківський менеджмент / П. Роуз / Переклад 3 англ. Наук. Редакція перекладу I. Рогозін. - К.: Вектор, 2013. - С. 107-179.

Рецензент д.е.н., професор ДДМА Рекова Н.Ю. Експерт редакційної колегї к.е.н., дочент УкрДУЗТ Зубенко В.О. 